\title{
The Philosophical Arguments in the Dispute over Artificial Reproduction in Italy in the Years 2004-2014*
}

\author{
Argumentacja filozoficzna w sporze o sztuczne zapłodnienie \\ we Włoszech w latach 2004-2014
}

\author{
Andrzej Kobyliński \\ Institute of Philosophy, Cardinal Stefan Wyszyński University in Warsaw, Poland \\ ORCID: https://orcid.org/0000-0003-2252-8634 • a.kobylinski@uksw.edu.pl
}

\begin{abstract}
In Italy for the last decade, a very interesting public debate has been conducted about artificial reproduction. An important step in this discussion was the adoption in 2004 of a special law regulating the use of the in vitro method. In 2014 the Constitutional Court cancelled the prohibition, existing in this document, of the methods of heterological artificial reproduction. A very important part of the debate in Italy are different kinds of philosophical arguments. The most interesting or very representative voices in this discussion include statements of Oriana Fallaci, Vittorio Possenti, and Gianni Vattimo.
\end{abstract}

Keywords: artificial reproduction, Oriana Fallaci, human embryo, non-negotiable values, Vittorio Possenti, Gianni Vattimo

Streszczenie: We Włoszech od dziesięciu lat toczy się bardzo interesująca debata publiczna na temat sztucznego zapłodnienia. Ważnym krokiem w tej dyskusji było uchwalenie w 2004 r. specjalnej ustawy regulującej stosowanie metody in vitro. W 2014 r. Trybunał Konstytucyjny uchylił istniejący w tym dokumencie zakaz stosowania metod sztucznego rozrodu heterologicznego. Bardzo ważną częścią debaty we Włoszech są różnego rodzaju argumenty filozoficzne. Do najciekawszych lub najbardziej reprezentatywnych głosów w tej dyskusji należą wypowiedzi Oriany Fallaci, Vittoria Possentiego i Gianniego Vattima.

Słowa kluczowe: sztuczne zapłodnienie, Oriana Fallaci, ludzki embrion, wartości nienegocjowalne, Vittorio Possenti, Gianni Vattimo

\section{Introduction}

In Italy, since 2004, the law regulating the use of the in vitro is in force. The passing of this law was preceded by the multi-annual social debate and political dispute. A national referendum held in 2005 can be considered as the culmination of the conflict. In recent years, the law regulating this matter was amended several times. The most controversial was the decision of the Constitutional Court of April 2014, which resulted in raising the earlier ban on heterologous in vitro fertilization (Casini 2014).

Why in recent years has the discussion on assisted reproduction in Italy become more concerned with legal than ethical issues? What factors influence the change of bioethical awareness of Italian society? What is the position of the representatives of the main philosophical currents in this debate? What to infer from Oriana

\footnotetext{
"This article was originally published in Polish as Kobyliński, Andrzej. 2015. „Argumentacja filozoficzna w sporze o sztuczne zapłodnienie we Włoszech w latach 2004-2014." Studia Ecologiae et Bioethicae 13(2): 69-91. The translation of the article into English was financed by the Ministry of Science and Higher Education of the Republic of Poland as part of the activities promoting science - Decision No. 676/P-DUN/2019 of 2 April 2019. Translation made by GROY Translations.
} 
Fallaci's words, who just before her death wrote poignantly about Greek Medea eating her own children? What regulations by law, relating to in vitro fertilization, may be introduced in Italy in 2015 ?

\section{Fertility - infertility - demography}

The current bioethical awareness of the Italian society and views on in vitro are well illustrated by the results of the opinion poll presented in Rome on 1 October 2014. This research project was entitled "Becoming parents today. Report on fertility/infertility in Italy", which was implemented by the Centre for Social Investment Studies (Centro Studi Investimenti Sociali - CENSIS) and by the IBSA Foundation (Fondazione IBSA). Since the 1960s, CENSIS prepares an annual report on the social situation of the country, and it is considered the most authoritative and comprehensive source of knowledge about social life in Italy (CENSIS 2014). Whereas, the IBSA foundation was established in the autumn of 2012 in Switzerland as a non-profit organization that supports and promotes the development of scientific research.

The results of the latest opinion poll carried out by CENSIS and IBSA might be considered as the most reliable source of information on the climate of opinion in Italy in 2014. What can one learn from this research? It turns out that $73 \%$ of Italians are in favour of the admissibility of the homologous in vitro fertilization, while heterologous in vitro fertilization is accepted by $40 \%$. This means that in this case the Italian society is very divided and the majority of inhabitants do not accept heterologous in vitro fertilization. $35 \%$ of Italians are in support of the pre-implantation diagnosis. $14 \%$ are in support of surrogacy and $9.5 \%$ of the possibility of choosing the sex of the child. The survey shows that $29 \%$ of Italians accept the right to raise children by homosexual couples.

The CENSIS and IBSA poll paid special attention to the current demographic catastrophe in Italy. In 2013, there was a decrease in the number of births of $3.7 \%$ compared to 2012 Italy, along with countries such as Poland and Slovakia, has the lowest total fertility rate in the world, placing 203 out of 224 countries. Birth statistics in Italy have been kept since 1862 and never in the history of this country have so few children been born as in 2013. Currently, only $29 \%$ of Italians under the age of 35 have children. In 2008, when the current economic crisis began, 576,659 children were born in Italy, and in 2013 only 514,308. However, the population of Italy is growing due to the arrival of immigrants. Every year, the number of them is exceeding 300,000 (De Marco and Forti 2014).

The vast majority of respondents (approx. 90\%) blame the current economic crisis for the demographic catastrophe. $61 \%$ of respondents believe that birth rates would be higher if the more pro-social policies and state aid in form of tax reliefs or reduction of costs for education would be implemented. In the autumn of 2014, the Minister of Health presented the "Plan for fertility". Critics of this type of solution emphasise that it cannot work as there is a need for long-term, wide-scale actions concerning society, politics, world-view and economy (Blangiardo 2014). For several years, there has been a dispute in Italy over the project of the national plan for pro-family policy, which includes many proposals on tax and housing policies, employment or new solutions for helping to reconciling work and family life.

Paola Ricci Sindoni - the chairperson of the association called Science and Life (Scienza \& vita), which was created 10 years ago as part of a public campaign before 2005 in vitro referendum, in note no. 133 of 2 October 2014, responded to the results of this poll and said that they were a strong warning: today more than ever, it is necessary to intervene effectively through initiatives aimed at protecting fertility by reintroducing the value of natural physiological age rather than seeking solutions when it is too late for the natural birth of one's own child. In her opinion, in Italy, one can spot a kind of lack of understanding when it comes to procreative awareness and postulated be- 
haviour that protect the reproductive ability of men and women.

Supporters of artificial fertilization argue that the current demographic catastrophe should lead to the biggest deregulation of the implementation of the in vitro fertilization so that as many children as possible can be born. In the public debate, supporters of assisted reproduction, both homologous and heterologous, very often use the argument concerning demography. They aim to convince the public that the complete liberalisation of using the in vitro fertilization and the wide availability of this procedure will effectively contribute to increasing the fertility rate in Italy and will halt the current demographic crisis. Opponents of such solutions strongly reject such reasoning and point to the need of implementing relevant pro-family policy, greater support for the adoption of children and more effective infertility treatment.

Since 2003, within the The Gemelli University Hospital, operates the Saint Paul VI Institute, which specializes in research on reproductiveness and infertility. The director of the institute is prof. Riccardo Marana. He points to the high effectiveness of the natural method of treating infertility. During the 10 years, the work of institute contributed to 720 births, which means that for $15 \%$ of couples, the treatment was successful. The scientists from the Catholic University of the Sacred Heart point out that the in vitro procedures result in birth, but do not remove the cause of infertility. Infertility is very often a symptom of other health, mental, emotional problems, etc. Therefore, one should focus on the elimination of the causes of infertility and natural births. According to data provided by the Italian Ministry of Health, the effectiveness of the in vitro fertilization is $14.2 \%$. For opponents of artificial insemination, such procedures mean that medical science was defeated and "gives up on the treatment of real causes of infertility" (Vinai 2014).

In note no. 157 of the aforementioned "Scienza \& Vita" association of 15 October 2014, Paola Ricci Sindoni commented on the proposal of two companies, Face- book and Apple, that their young workers should freeze and store their oocytes to postpone the pregnancy so that it would not be an obstacle in their career. In her opinion, freezing egg cells can be a rational solution in case of occurrence of health problems, but it cannot be used by employers as a bargaining chip. The proposal of two companies, Facebook and Apple, is an evident manifestation of the process of modern technical development of maternity, which result might be the growing number of mature women having children by the use of in vitro fertilization.

On the 14 November 2014, the "Avvenire" newspaper published an article heterologous artificial fertilization: a slogan and reality which took up the issue of one of the aspects of technical development of maternity, namely buying and selling reproductive cells. Its author, Francesco Ognibene, pointed out that in the dispute over in vitro, one can spot a kind of semantic revolution: concepts such as freedom, love, justice, equality or discrimination gain new meaning.

According to the author of the article, the irresponsible abuse of the notion of the gift is particularly arduous (Ognibene 2014). A gift is connected with selflessness, the reversal of the commercial relationship of buying and selling, something is given with a pure desire of gifting and expecting nothing in return, which exceeds the ground rules of the market. Ognibene claims that the concept of gift should be used in the context of the acquisition of gametes used in the heterologous assisted reproduction process only in exceptional circumstances. Most often, the price of gametes is determined by the law of markets: when importing oocytes from other countries, in Italy one is to pay approx. EUR 2,800, while the amount of sperm needed for performing one in vitro fertilization attempt costs approx. EUR 400.

\section{Oriana Fallaci and Medea's offspring}

In the last dozen years, the article written by well-known writer and journalist Oriana Fallaci presented the firmest opinion 
in this Italian dispute. Her poignant and dramatic text was published on 3 June 2005 in the biggest Italian daily newspaper "Corriere della Sera" and it shocked the public. The article was titled We cannibals and Medea's offspring (Fallaci 2005). In the article, which expresses strong criticism towards many modern forms of eugenics and new biotechnologies, one can read about "slaughter of innocents" and the temptation of "new Frenkensteins", and in its radical and emotional approach, it resembled of the author's famous book The Rage and the Pride (Fallaci 2002; Cecchi 2013; De Stefano 2013), which was written after the terrorist attacks on the World Trade Center in New York on 11 September 2001.

Oriana Fallaci, calling herself a "Christian atheist", criticized the artificial fertilization methods from humanistic, non-religious and strictly moral point of view. In Italy, the notion of "Christian atheism" means a specific kind of worldview held by a rather influential group of intellectuals who, as atheists or agnostics, discern a need to protect the Christian tradition as the foundation of freedom and democracy in Western civilization. Journalists often refer to this group of people as "devout atheists". In public domain, this group is also referred to as supporters of "Christianity without Christ", who as agnostics or atheists, paraphrasing the famous maxim of Hugo Grotius, live as if God existed (etsi Deus daretur).

The followers of "Christian atheism" claim that today the protection of Christian values as the foundation of the West is becoming particularly essential due to the threat posed by the expansion of Islam. Supporters of the role of Christianity as the foundation of Western civilization believe that a possible crisis of values would inevitably lead to the disappearance of the European and Western cultural model, which is based on freedom and democracy. The similar attitude in the past characterized thinkers such as the German philosopher Leo Strauss or, in France, Charles Maurras, the founder of conservative, monarchist movement "French Action", who described himself as a "Catholic atheist". In the first decade of the 21st century, many Italian politicians and intellectuals have declared themselves to be "Christian atheists", e.g. famous politician and journalist Giuliano Ferrara or former President of the Senate of the Republic of Italy, Marcello Pera (Cardini 2002; Pera and Ratzinger 2004; Quagliariello 2006).

In early 2005 Fallaci has publicly announced that she will not participate in the in vitro referendum. By boycotting the referendum, she aligned herself with the conservative supporters of Law 40/2004. The Italian writer and journalist accused the supporters of the referendum, who wanted the liberalization of the use of assisted reproduction, of moral short-sightedness and called them "patrons of the doctor Frankenstein". In her opinion, the Italian society in 2005 did not need a referendum and wide access to in vitro but rather an explanation that unlimited freedom, i.e. uncontrollable and deprived of moral meaning, is no longer freedom, but a license. Ignorance, one's own fantasy. The point is to clarify that in order to maintain and protect freedom, one has to impose restrictions on it, using reason, common sense and ethics. It is about recognizing the difference between what is permitted and what is prohibited (Fallaci 2005).

In her emotional article, Fallaci disagreed with justifying of the so-called therapeutic cloning, which promises to treat a variety of diseases in the future. She stated that the referendum means a project of re-creating human in a laboratory, turning it into a product for sale like a steak or a bomb. It is a proposal to replace nature, manipulate nature, alter or even obliterate the foundation of life, dehumanization of its, slaughtering the weakest and defenceless creatures, i.e. our unborn children, human embryos sleeping in the freezers of banks or research institutes (Fallaci 1975).

According to Fallaci, such practices refer to the Brave New World, written in 1931 by Aldous Huxley (1932). They are even more reminiscent of the barbarism of the eugenics of Adolf Hitler, who dreamt of a society consisting only of blondes with 
blue eyes. Fallaci wrote that it reminds her of concentration camps of Auschwitz, Mauthausen, Dachau and Birkenau, where in order to accelerate the production of the Aryan race, i.e. to increase the birth of blondes with blue eyes, Dr Mendele performed pseudo-medical experiments on twins. Using the limitless freedom of research that Hitler granted him, he killed children and sometimes performed vivisection on them. Fallaci claimed that if to put democratically managed research institutes in place of Birkenau or Dachau, if we put human embryos that sleep in freezers in place of twins that are vivisected by Mengele, then there is no difference between these actions (Fallaci 2005).

The author of the article We cannibals and Medea's offspring, many times has spoken about the modern "holocaust of human embryos" (l'olocausto degli embrioni umani). She claimed that an embryo is a human being that feels and suffers like adult people (Fallaci 1975). Therefore, it cannot be sacrificed at the altar of science, progress and interest of the civilization. This is why humans need the priority of ethics over science.

Fallaci wrote that science is like fire. That it can contribute to good but also evil. That it can, just like fire, warm up, clean up and save people or turn them into ashes and destroy them. She claimed that it often does more bad than good and the cause of that is that science, just like fire, is not concerned with moral problems. She stated that for science, all that is possible is at the same time allowed (Fallaci 2005).

If we do not want to lose respect for human, we must demystify scientific research, which can no longer be treated as new deities. Science cannot create ethos on its own. A renewed ethical consciousness will not appear from scientific debate alone, if a human wants to overcome contemporary dehumanization and objectification, one has to return to the foundations of our morality. The Italian writer and journalist also criticized the contemporary understanding of bioethics. She pointed out that today, various bioethical committees justi- fy actions that are simply unethical in their deepest essence too often.

She stated, that the issue is that in the modern times, ethics "gave birth" to bioethics which is its "degenerated daughter". She mentions Erwin Chargaff and claims that she has the same opinion on this topic as this American biochemist, who allegedly used to shout that ethics is to bioethics what music is to military march whenever he heard someone talking about assisted fertilization or artificial insemination or frozen embryos. She pointed out that the Western world is "swimming" in the aforementioned "military marches". In the Western world, the author highlighted Bioethics Institutes, Bioethics Committees and Bioethics Academies (Fallaci 2005).

Particularly poignant were the very personal words of this Italian writer and journalist, when she spoke openly about her own fight against several different types of cancer, which she finally lost on 15 September 2006, and her lack of consent to save her life by using embryonic stem cells, in process of creation of which, human embryos are killed. Mentioned human embryos used in this process are created specifically for this purpose by so-called therapeutic cloning or are so-called extra embryos, created in the process of artificial insemination.

Fallaci stated, a year before she died, that she wants to live as long as possible and that she is "in love with life", but claimed that if she would choose to treat cancer by injecting embryo of an unborn baby, she would be a cannibal. She stated, that she would be like Medea, who kills her own offspring. ("You abomination! Of all women most detested. By every god, by me, by the whole human race! May the gods blast your life!" - says Jason to Medea in this Europides' play) (Fallaci 2005).

\section{Vittorio Possenti's personalism}

In the years 2005-2014, during the conflict concerning the liberalization of the law of 2004, regulating the use of the in vitro method and many journalistic disputes, one could also see an in-depth scientific 
debate on this topic. The reports, studies, scientific conferences, research projects, social initiatives, foundations and associations established, and published books are a meaningful testimony of this period (Bucelli 2006; Martini 2006; Flamigni 2007; Dossetti 2010; D'Amico and Clara 2010; Barenghi 2011; Marzano 2011; Pugliese 2011; Betta 2012; Borini and Flamigni 2012; Caporale 2012; De Santis 2012; Scia 2012; Vari 2012; Aiello and Pistone 2013; Cossiri and Di Cosimo 2013; Iagulli 2013; Mansueto 2013; Cittadini and Carrillo 2014).

The very important elements of the debate in Italy, are the statements of philosophers and intellectuals representing various fields. The most in-depth philosophical discussion, which took place in 2005 , concerned the topic of beginning of human life. The majority of Italian philosophers took part in it (Kobyliński 2007). One of the leaders of the opposition to in vitro, trying to limit this procedure as much as possible, is Vittorio Possenti. The main figure for the supporters of assisted reproduction, who postulate complete deregulation, is Gianni Vattimo. One might say that in the last ten years, these two names have been determining the area for philosophical discussion about in vitro in Italy.

Possenti is a member of the National Committee for Bioethics and a founder of the Inter-faculty Center for Research on Human Rights at the Cà Foscari University in Venice. He is an important representative for personal bioethics. In his opinion, the use of in vitro fertilization involves many sensitive moral and legal problems, which include the existence or non-existence of the right to have a child, gamete (stem cell) trade, (ir)responsibility of biological parents, the child's interest in learning about its own roots, (in)adequacy of the term "donor" concerning the transfer of gametes used in heterologous in vitro fertilization (Possenti 2013, 169-171).

Among the most important reasons for opposition to assisted reproduction, Possenti points out that, in many countries, thousands of human embryos are de- stroyed due to the high difficulty or even impossibility of implantation of those into the mother's body According to this author, promoter and advocate of ontological personalism, the main area of reflection on bioethical issues should not be ethics but rather ontology. Ontological research and analysis show the importance of moral commitment, assuming that the emerging ontological structures convey the connotations of such values that "demand or impose obligations on our freedom" (Possenti 2006, 124; Possenti 2009, 137-152).

The Venetian philosopher identifies the individual with a person and calls the human embryo the individual from the moment of conception, and in the consequence, he states that the human embryo is already a person when it still is a zygote and therefore, should have all human rights, and above all the right to life. According to the Potentiality Principle, there is an ontological continuity between zygote and adult (Mordacci 2010, 213; Berti 2010, 185-197).

Possenti points out that there has been a violation of the basic ethical concept of responsibility by the biological parent. This concept assumes that a person is responsible for the foreseeable consequences of their behaviour and accepts the responsibility connected to it. The moral irresponsibility of the person donating their own reproductive cells towards the child who is born of them is objective and obvious in the sense that the gametes donor does not assume any responsibilities towards the child. The biological parent consciously detaches themself from relationship from the very beginning and does not assume any obligations towards the child, thus depriving the child of the knowledge of their origin and relationship with the biological parents.

The Venetian philosopher claims that artificial heterologous insemination assumes implicite as the basis for its "criterion of irresponsibility", which denies the foundation of ethical concept of responsibility, which constitutes a foundation of social life and principle relevant for human and his or her dignity. Medically assisted 
heterologous procreation particularly encourages irresponsibility among men.

If gametes are sold, procreation enters the material sphere of economic values, introducing a criterion of moral disorder at the root of the procreation. The situation improves if the children is being guaranteed the right to know their roots and the identity of the biological parents, but also in this situation, disadvantage of the responsibility concept, created by the heterologous in vitro method in relation to the primary relationship and the relationship between parents and children, remains.

The relationship between parents and children is fundamental, because among many social figures, this one is the most common: if not everyone are fathers and mother, definitely everyone are children, and being a child includes its relationship with parents and their duties and responsibilities towards it. Artificial heterologous insemination separates "biological parenthood" from "social parenthood", encouraging the unacceptable irresponsibility of biological parents in the fundamental and most universal sphere of human relationship.

\section{Gianni Vattimo's postmetaphysical bioethics}

One of Italian philosophers who strongly advocates the legalization of in vitro fertilization in all its forms is, born in Turin, Gianni Vattimo. He is a supporter of postmetaphysical bioethics and accepts almost all the achievements of the modern biotechnology revolution. His views, similar to Peter Singer's utilitarianism, are representative for a large number of Italian supporters of using in vitro fertilization. Vattimo strongly rejects the possibility that a human embryo is a person. In relation to an embryo, he uses the term "potential human life", which can develop, in suitable conditions, into a human capable of making moral decisions and actions. For the philosopher from Turin, the human embryo is a form of human life, but is not a human being in a sense of a person, it will become one after it is born. It is a typical recognition of potential of human embryo.
According to this view, the beginning of embryonic life does not mean the beginning of life of a person. Vattimo claims that a human embryo has a potential to become a person (Vattimo 2008, 7).

He writes that human life begins when an entity capable of claiming its right and fulfilling its duties is being born and That every other life is human only if corresponds to it (Vattimo 2006, 34). The essence of humanity is the awareness of one's rights. Do the so-called nuda vita devoid of vivendi causas have sense? In his opinion, values such as culture, intersubjective relationships, the desire to leave a happier world for future generations, not to mention the hope of afterlife, do not have much in common with pure and simple "biological survival".

If Vattimo had to choose between respect for the embryo, which cannot communicate and assert its rights, and the expectations of sick people who are waiting for treatment with embryonic stem cells obtained from human embryos, or the rights of couples who cannot have children and want to benefit from the medically assisted conception, he would support people whom one can see and touch and who, above all, are aware of their rights and can assert them. He claims that such issues should be left to the individual decision of the people concerned. He strongly rejects the views of people like Oriana Fallaci, who claim that in vitro can be compared with the extermination of the disabled and defenceless. The most important question is not whether the embryo is already a person, but whether there is a "natural law", which can be imposed on those who do not believe in it. Vattimo claims that the so-called natural laws are much less effective in protecting the weak than the conscious beliefs and laws that every society develops. The law what is recognised as binding by the state under the rule of law based on free discussion of its citizens. Social conventions stem from one's responsibility, which determines one's perception of good and evil, regardless of what could appear as more or less natural. Most often, people who can impose their own value 
systems and evaluation criteria, not always selflessly, are the one's who are "right".

Vattimo believes that protecting the right to life of every human embryo does not make any sense if one does not take into account its specific possibilities to make its own life worth living. He strongly rejects the belief in the sacredness of life and accuses the pro-life supporters of idolatry. When a conflict of values emerges, e.g. using extra embryos, created in the in vitro procedure, for scientific research, one should ask, what is the point of protecting nuda vita at all costs? Vattimo postulates ethical minimalism. There is no point in comparing the value of the rights of embryos used for stem cell research with the ones used to save people, who live a full life or friends, who are dying or are wheelchair-bound. The philosopher claims that the history of humanity continues through the sacrifice of many people's lives. History needs sacrifices, including embryos that are created by the in vitro procedure.

According to the post-metaphysical views of this philosopher, the rights of an embryo are not rooted in human nature, but in history and social life. In his opinion, there are many different philosophical stances and scientific theories on the question of the beginning of human life or the use of methods of artificial insemination. In the case of such pluralism, one should not impose a single binding concept on everyone. As a consequence, one should preserve a diversity of opinions and freedom of thought.

\section{Are there any non-negotiable principles and values?}

A distinct prevalence of legal over ethical problems in the dispute over the topic of in vitro over the past few years and passive attitude of Catholic communities, especially after the decision of the Constitutional Court of spring 2014, have raised some difficult questions concerning the change of the cultural climate in Italy. The current shape of the debate is all the more astonishing if one compares it with a very emotional and morally oriented ideological dispute during the process of shaping the law in 2004 and during the referendum in 2005.

Surely, there are many reasons for this, but certainly one of the most crucial is the change that takes place in Catholicism in Italy and around the world. In Italy, the strongest resistance to assisted reproduction, both homologous and heterologous, has for years been mounted mainly by Catholic communities. They were a force that also inspired and united other communities that presented similar attitude concerning moral issues. Nowadays, one might get the impression that Italian Catholic communities are being withdrawn and less active than a few years ago in presenting their position in the public debate when it comes to moral or philosophical issues.

On 24 November 2002 the Doctrinal Note on some questions regarding the participation of Catholics in political life was published by the Congregation for the Doctrine of the Faith. The aim of this Note was to recall some of the principles that Catholics, guided by their Christian conscience, should follow in undertaking social and political tasks in democratic societies. In this document, for the first time in the history of The magisterium of the Catholic Church, the notion of non-negotiable values, i.e. principles that cannot be the subject to any compromises, because they concern life, dignity and future of humankind.

In the Note one can read, "Christians must recognize the legitimacy of differing points of view about the organization of worldly affairs, they are also called to reject, as injurious to democratic life, a conception of pluralism that reflects moral relativism. Democracy must be based on the true and solid foundation of non-negotiable ethical principles, which are the underpinning of life in society" (The Congregation for the Doctrine of the Faith 2002).

The following three principles were considered non-negotiable by the Catholic Church: firstly, protection of life from conception to natural death, i.e. opposition to abortion, euthanasia and genetic manipulation on humans; secondly, pro- 
tection of monogamous marriage as a union of man and female, i.e. opposition to the legalisation of homosexual unions and any attempt to equate other unions with the traditional form of monogamous marriage; thirdly, protection of the principle of freedom of education, i.e. right of a family to decide the method of parenting and choosing a suitable school.

For many years in the dispute over in vitro in Italy, very often the representatives of many different Catholic communities used the term "non-negotiable values". Priests and laypeople stressed that artificial insemination violates dignity and contributes to destruction of many human lives. The climate of this discussion has changed after the election of Pope Francis, who emphasizes the need to preach the Gospel rather than protect moral principles. Because of that, the concept of non-negotiable values suddenly disappeared from the Italian public debate.

In February 2014 an interview with Pope Francis was published in "Corierre della Sera". The interviewer, Ferruccio De Bortoli asked the Pope: "In the recent years, people commonly referred to the so-called non-negotiable values, especially concerning bioethics and sexual morality. Your Holiness has not done that. Doctrinal and moral principles have not changed. Does this decision indicate, perhaps, a less authoritative and more respectful of personal conscience style? - I have never understood the expression non-negotiable values - Pope Francis replied. Values are values, and that is it. I can't say that, of the fingers of a hand, there is one less useful than the rest. Whereby I do not understand in what sense there may be negotiable values. What I wanted to say about life, I stated in Evangelii gaudium" (De Bortoli 2014, 3).

At the beginning of 2014, Archbishop Víctor Manuel Fernández, rector of the Pontifical Catholic University of Argentina in Buenos Aires, a longtime advisor to the present Pope, often called his personal theologian, explained very precisely the current change in the cultural climate among Catholics. Archbishop Fernández described it in a book The Francis project. Where he wants to take the Church, which he wrote together with Paolo Rodari, an Italian journalist and Vaticanist working for "La Repubblica" (Fernández and Rodari 2014).

According to Fernández, the essence of the Pope's revolutionary programme is the primacy of preaching the Gospel over protecting moral principles. In this point of view, the category of non-negotiable ethical principles can lead to fanatical attitudes and a constant conflict over the same issues. Certainly, Pope Francis does not change the Church's official teachings, but he introduced a new approach. He is a strong opponent of abortion and euthanasia, but at the same time he highlights the values such as loving one's neighbour or doing justice to the poor and oppressed (Magister 2014).

On 13 November 2014 in the Italian newspaper "ItaliaOggi", an interview by Goffredo Pistelli was published. The author spoke with Sandro Magister, one of the most famous Vaticanists, who for 40 years has been commenting on religious, moral and world-view issues for the Italian weekly "L'Espresso" (Pistelli 2014). Magister's statements consist of extremely objective and philosophically in-depth analyses of the current cultural condition. Already in Autumn 2013, this Vaticanist was first to present the new approach of Pope Francis to the contemporary anthropological revolution concerning evangelism. In the interview for the "ItaliaOggi", Magister confirms his previous opinions, which are in line with the words of the rector of the Pontifical Catholic University of Argentina.

\section{Conclusions}

The decision of the Constitutional Court started a new phase in the dispute over the contemporary biotechnology revolution. In the summer of 2014, a political decision was made by the cabinet of Matteo Renzi that a new law should be adopted in Italy to regulate the use of heterologous assisted reproduction. The relevant law should be adopted in 2015. A difficult discussion in the parliament on these 
issues is to be expected because $60 \%$ of the population does not accept heterologous artificial insemination, while only $40 \%$ of Italians support the use of such medical procedures.

At this stage, one of the most difficult issues to resolve is one of the anonymity of gametes donors and the right of children to know about their biological roots. Another major challenge includes limiting or prohibiting the production of the so-called extra embryos so that there is no unrestricted process of freezing and destroying human life on its first stage of development.

The last 10 years of the dispute over the use of in vitro method in Italy clearly shows the moral and philosophical changes that take place on our continent and in many other regions of the world. While the adoption of the law in 2004 resulted in even greater national debate on ethics, the responses after the decision of the Constitutional Court of the Republic of Italy of spring 2014 were mostly concerned with legal issues. It seems that in this case, one can legitimately speak of the growing primacy of law over ethics. Until recently, something that was considered primarily as an ethical problem, today very often becomes a typical legal issue. This has been clearly articulated in August 2014 by the Italian Minister of Health, Beatrice Lorenzin, who pointed out the necessity of disassociating all bioethical elements from in vitro dispute. Her shocking statement did not actually caused strong reaction in Italy and remained virtually unnoticed.

The shape of the current discussion on the medical staff right to conscientious objection can also be seen as the proof of a profound change in the cultural climate. In mid-November 2014 the main opinion-forming newspapers in Italy have discussed the topic of limitations or even reasonability of making conscientious objection by medical staff. Opponents of this right present it as a kind of killer of the right to abortion. As a result, the left-liberal Italian press presents gynaecologists who do not use this right as a kind of heroes. In the autumn of 2014 many articles accusing doctors, who make a conscientious objection and do not perform legally allowed abortions, of committing a crime, were published. Authors of these articles claim that those decisions foster the abortion underground. Many politicians, lawyers and journalists call for their penalizing, either monetary or by blocking their promotion.

The dispute over in vitro shows that having a child should be a desire and not a right. If having a child is to be a right, then all measures that result in meeting such expectation, become allowed. Today, a joint effort is needed of all people of good will to stop the progressing process of technical development and dehumanization of our lives.

One of the manifestation of this dangerous process is the growing social aspiration to have at all cost the so-called perfect child, whose traits are determined by pre-implantation genetic diagnosis or by the choice of particular gametes for in vitro fertilization. The contemporary biotechnology revolution cannot lead, as Oriana Fallaci noticed, people to behave similarly to the Greek Medea from Euripides' play.

\section{Bibliography}

Aiello, Raffaele, and Espedito Pistone. 2013. Infertilità di stato. Il desiderio di maternità tra legge 40 e viaggi della speranza. Napoli: Iuppiter Edizioni.

Barenghi, Andrea. 2011. Procreazione assistita e tutela della persona. Atti del Convegno tenutosi a Roma 30 maggio 2010. Padova: Casa Editrice CEDAM.

Berti, Enrico. 2010. "La nozione di forma come condizione dell'identità personale." In Metafisica, persona, cristianesimo. Scritti in onore di Vittorio Possenti, edited by Giuseppe Goisis, Marco Ivaldo, and Gaspare Mura, 185197. Roma: Armando Editore.

Betta, Emmanuel. 2012. Laltra genesi. Storia della fecondazione artificiale. Roma: Carocci Editore.

Blangiardo, Gian Carlo. 2014. "Un «Piano per la fertilità»? Il Paese può ripartire da qui." $A v$ venire 47(185): 3. 
Borini, Andrea, and Carlo Flamigni. 2012. Fecondazione e(s)terologa. Roma: L'Asino d'Oro Edizioni.

Bucelli, Andrea. 2006. Produrre uomini. Procreazione assistita: un'indagine multidisciplinare. Firenze: Firenze University Press.

Caporale, Maria. 2012. Le sfide della scienza. Il diritto alla procreazione. I diritti del nascituro. Roma: Universitalia Editore.

Cardini, Franco. 2002. La paura e l'arroganza. Roma: Editori Laterza.

Casini, Marina. 2014. "Il «figlio a tutti i costi»e la procreazione medicalmente assistita. Così la Corte Costituzionale dimentica il primato degli interessi e dei diritti dei minori. La sentenza n. 162 del 2014 e il ritorno dell'eterologa in Italia." Medicina e morale 63(3): 367404. https://doi.org/10.4081/mem.2014.55.

Cecchi, Umberto. 2013. Oriana Fallaci. Cercami dov'è il dolore. Firenze: Mauro Pagliai Editore.

CENSIS. 2014. $48^{\circ}$ Rapporto sulla situazione sociale del Paese/2014. Milano: Edizioni Franco Angeli.

Cittadini, Ettore, and Laura Carrillo. 2014. La preservazione della fertilità. Concepire dopo la malattia. Roma: L'Asino d'Oro Edizioni.

Cossiri, Angela Giuseppina, and Giovanni Di Cosimo. 2013. La fecondazione vietata. Sul divieto legislativo di fecondazione eterologa. Roma: Aracne Editrice.

D’Amico, Marilisa, and Massimo Clara. 2010. La Cicogna e il codice. Fecondazione assistita, riflessioni e prospettive. Milano: Edizioni Franco Angeli.

De Bortoli, Ferruccio. 2014. "«Vi racconto il mio primo anno da papa» - a conversation with Pope Francis." Corriere della Sera 54: 2-3.

De Marco, Manuela, and Oliviero Forti. 2014. XXIII Rapporto Immigrazione Caritas - Migrantes "Tra crisi e diritti umani". Roma: Fondazione Migrantes.

De Santis, Dario. 2012. I fabbricanti di uomini. Storia delle prime fecondazioni artificiali sul genere umano. Bologna: Edizioni Pendragon.

De Stefano, Cristina. 2013. Oriana. Una donna. Milano: Casa Editrice Rizzoli.

Dogliotti, Massimo, and Alberto Figone. 2004. Procreazione assistita. Assago: Editore Ipsoa.

Dossetti, Maria. 2010. Cinque anni di applicazione della legge sulla procreazione medical- mente assistita. Problemi e responsablità. Atti della Giornata di studio tenutosi a Milano 30 settembre 2009. Milano: Giuffrè Editore.

Fallaci, Oriana. 1975. Lettera a un bambino mai nato. Milano: Casa Editrice Rizzoli.

Fallaci, Oriana. 2002. The Rage and the Pride. Milano: Casa Editrice Rizzoli.

Fallaci, Oriana. 2005. "NOI cannibali e i figli di Medea." Corriere della Sera 151: 8-9.

Fernández, Víctor Manuel, and Paolo Rodari. 2014. Il progetto di Francesco. Dove vuole portare la Chiesa, Bologna: Edizioni EMI.

Flamigni, Carlo. 2007. Diario di un laico. Viaggi, incontri e scontri sulla legge per la procreazione assistita. Bologna: Edizioni Pendragon.

Gallo, Filomena, and Chiara Lalli. 2012. Il legislatore cieco. I paradossi della legge 40 sulla fecondazione assistita. Roma: Editori Internazionali Riuniti.

Huxley, Aldous. 1932. Brave New World. London: Chatto \& Windus.

Iagulli, Paolo. 2013. Diritti riproduttivi e fecondazione artificiale. Studio di sociologia dei diritti umani. Milano: Edizioni Franco Angeli.

Kobyliński, Andrzej. 2007. "Czy embrion jest osobą? Spór o sztuczne zapłodnienie we Włoszech." Studia Ecologiae et Bioethicae 5: 157-172.

Magister, Sandro. 2014. "La paziente rivoluzione di Francesco." Settimo cielo, October 24, 2014. http://chiesa.espresso.repubblica.it/articolo/1350910.

Mansueto, Rosanna. 2013. Mamma a tutti i costi. Roma: Sovera Edizioni.

Martini, Alessandro. 2006. Profili giuridici della procreazione medicalmente assistita. $\mathrm{Na}$ poli: Editoriale Scientifica.

Marzano, Michela. 2011. Etica oggi. Fecondazione eterologica, "guerra giusta», nuova morale sessuale e altre grandi questioni contemporanee. Trento: Centro Studi Erickson.

Mordacci, Roberto. 2010. "L'embrione umano fra natura e identità personale." In Metafisica, persona, cristianesimo. Scritti in onore di Vittorio Possenti, edited by Giuseppe Goisis, Marco Ivaldo, and Gaspare Mura, 213-225. Roma: Armando Editore.

Ognibene, Francesco. 2014. "Eterologa: slogan e realtà. Non giocate col dono." Avvenire 47(269): 1.

Pazienza, Daniela. 2004. Io e la fecondazione assistita. Roma: Armando Editore. 
Pera Marcello, and Joseph Ratzinger. 2004. Senza radici. Milano: Arnoldo Mondadori Editore.

Pistelli, Goffredo. 2014. "Il Papa disorienta molti vescovi. Perché gioca su più piani e spesso si contraddice anche - intervista con Sandro Magister." Italia Oggi 269: 11-12.

Possenti, Vittorio. 2006. Il principio-persona. Roma: Armando Editore.

Possenti, Vittorio. 2009. Dentro il secolo breve. Soveria Mannelli: Casa Editrice Rubbettino.

Possenti, Vittorio. 2013. La rivoluzione biopolitica. La fatale alleanza tra materialismo e tecnica. Torino: Edizioni Lindau.

Pugliese, Vincenzo. 2011. Il diritto a diventare genitori. Procreazione medicalmente assistita e caduta di divieti. Roma: Editori Laterza. Quagliariello, Gaetano. 2006. Cattolici, pacifisti, teocon. Chiesa e politica in Italia dopo la caduta del Muro. Milano: Arnoldo Mondadori Editore.

Scia, Fausta. 2012. Indagini genetiche preimpianto e procreazione medicalmente assistita. Napoli: Edizioni Scientifiche Italiane.
The Congregation for the Doctrine of the Faith. 2002. Doctrinal Note on Some Questions Regarding the Participation of Catholics in Political Life. Vatican City: Libreria Editrice Vaticana.

Vari, Filippo. 2012. La fecondazione eterologa tra costituzione italiana e convenzione europea dei diritti dell'uomo. Atti del seminario tenutosi a Roma 2 aprile 2012. Torino: Editore Giappichelli.

Vattimo, Gianni. 2006. La vita dellaltro. Bioetica senza metafisica. Cosenza: Marco Costantino Editore.

Vattimo, Gianni. 2008. "Una bioetica post-metafisica." In Ragione filosofica e fede religiosa nell'era postmoderna, edited by Dario Antiseri and Gianni Vattimo, 5-16. Soveria Mannelli: Casa Editrice Rubbettino.

Vinai, Emanuela. 2014. "Cure per la sterilità più efficaci della fecondazione assistita." Avvenire 47(187): 10. 